\title{
Association of ACE DD genotype with Hypertension among the tribal populations of South India.
}

\author{
Raghu Paramasivam ${ }^{1, a}$, Nandakumar Rangasamy ${ }^{\star 2, b}$ Deva Arumugam $^{3, c}$, \\ and Prabhakaran Krishnan ${ }^{4, \mathrm{~d}}$.
}

${ }^{1}$ Research Scholar, PG and Research Department of Zoology, Periyar E.V.R College, Tiruchirappalli- 620023, Tamilnadu, India.

${ }^{2}$ Research Scholar, PG and Research Department of Zoology, Periyar E.V.R College, Tiruchirappalli- 620023, Tamilnadu, India.

${ }^{3}$ Research Scholar, PG and Research Department of Zoology, Periyar E.V.R College, Tiruchirappalli- 620023, Tamilnadu, India

${ }^{4}$ Assistant Professor, PG and Research Department of Zoology, Periyar E.V.R College, Tiruchirappalli- 620023, Tamilnadu, India.

Corresponding Author: R. Nandakumar, Research Scholar, PG and Research Department of Zoology, Periyar E.V.R College, Tiruchirappalli- 620023, Tamilnadu, India.

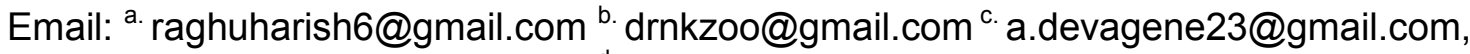 \\ and d.pkp601@rediff.com
}

Keywords: Tribal, Dravidian, ACE DD genotype, Hypertension, South India

\begin{abstract}
The Renin-Angiotensin System (RAS) is an important regulator of the blood pressure(BP). The level of the vasoactive peptide Angiotensin-II, is mainly determined by the RAS enzyme, angiotensin converting enzyme-1 (ACE-1). Polymorphisms in ACE gene is reported to be associated with hypertension in various populations worldwide. We investigated the association of ACE I/D polymorphisms with hypertension among the tribal populations of South India. Samples were collected from hypertensive patients $(n=33)$ and healthy controls $(n=37)$. Genotyping was performed using Polymerase chain reaction (PCR) with allele specific primers. The DD genotype is significantly observed among the cases $(\mathrm{OR}=1.0)$. Specifically, the DD genotype is more evident among the females $(\mathrm{OR}=0.705)$ than males $(\mathrm{OR}=1.22)$ and is analysed to be associated with hypertension among the tribal populations of South India.
\end{abstract}

\section{Introduction}

The Indian population has been an enigmatic subject for archaeologists, historians, anthropologists and geneticists for many decades, by virtue of its enormous linguistic, historic and cultural diversity [1]. The dominant and most powerful key cultural factor of the indian subcontinent is the caste system. Dating back to time immemorial, this system is characterized by its well stratified, endogamous and close-cultural values, which could strongly prohibit any exchange from outside. Genetically, this restriction significantly control the gene flow between the population subgroups, which creates specific genetic patterns, that could make the groups either susceptible or resistant to various diseases [2-3].

Numerous studies were reported at the context of disease epidemiology and genetics, upon various indian tribal communities, who are highly isolated both demographically and topogra phically, from the mainstream indian populations [4-16].

The South Indian tribalcommunitiesrepresentaprimitive, negroid, proto-australoid population ancestry, which are characterized by their unique cultural practices and endogamy [17-21].

The angiotensin-I converting enzyme (ACE) gene is widely studied for its crucial roles in the Renin-Angiotensin system (RAS) and reported to be associated with Hypertension and other cardio and cerebro vascular diseases [22 - 23]. Many studies showed that polymorphisms of certain genes related to metabolism, including that of ACE, are also associated with the onset and development of Type 2- Diabetes [22, 24 - 25]. There is a 287 bp DNA fragment insertion (I) and /or deletion(D) polymorphism in the intron 16 of ACE gene $[22,26]$, which was recently studied [27-31] in the context of its association with Hypertension and Diabetes [22, 28 - 30, 32-35] in 
various populations worldwide. In this study, we examined the distribution of ACE I/D polymorphisms in their association with Hypertension among the tribal populations of Southern India.

\section{Subjects and methods:}

A total of 33 hypertensive patients and 37 healthy controls were included in this study, with blood pressure (BP) measured with standard mercury manometer. Subjects with BP 120/80 mmHg (SBP/DBP) were considered normal, and those with higher values (SBP $\geq 140 \mathrm{mmHg}$ and $\mathrm{DBP} \geq$ $90 \mathrm{mmHg}$ ) were considered hypertensive. The selected tribal communities are Mudhuvar, Pulaiyan, Mannan and Kaniyan. Blood samples $(5 \mathrm{ml})$ were collected from the subjects between the age of 15-85 years, with proper informed consents obtained. Genomic DNA was extracted from the whole blood using the Salting out method [ 36 ]. The isolated DNA was suspended and stored in $10 \mathrm{~mm}$ Tris and 0.1mM EDTA for genotyping. The polymorphic loci were genotyped (Table: 1) using the standard 30-cycle PCR. Appropriate annealing temperatures and additives were optimized for each system.The PCR protocols were followed as reported earlier [37- 38]. The amplicons were separated by electrophoresis. Later, the EtBr stained gels were visualized under UV.

\section{PCR Protocol:}

The total volume of the reaction mixture was $20 \mu 1$, which contained $13.5 \mu 1$ double distilled $\mathrm{H}_{2} \mathrm{O}, 2 \mu \mathrm{l} 0.5 \mathrm{X}$ PCR buffer (Agilent), $0.4 \mu \mathrm{l}$ of $10 \mathrm{mM}$ dNTPs (Genet Bio), $1 \mu \mathrm{l}$ of forward and reverse primers and $0.5 \mu \mathrm{l}$ Taq DNA polymerase (Agilent). PCR cycling conditions were as follows: 1) $95^{\circ} \mathrm{C}$ for $5 \mathrm{~min}$; 2) 30 cycles of $95^{\circ} \mathrm{C}$ for $45 \mathrm{sec}$; 3) $56^{\circ} \mathrm{C}$ for $30 \mathrm{sec}$;) $72^{\circ} \mathrm{C}$ for $30 \mathrm{sec}$ and 5) $72^{\circ} \mathrm{C}$ for $3 \mathrm{~min}$. PCR products were run on $2 \%$ agarose gels stained with Ethidium bromide and compared with a 100 base pair DNA ladder under UV illumination (Fig:1).

Table 1: PCR primers and Conditions

\begin{tabular}{|c|c|c|c|c|c|c|}
\hline \multirow{2}{*}{$\begin{array}{c}\text { DNA } \\
\text { Locus }\end{array}$} & \multirow{2}{*}{$\begin{array}{l}\text { Chromosome } \\
\text { location }\end{array}$} & \multirow{2}{*}{ Primer sequence } & \multirow{2}{*}{$\begin{array}{c}\text { Annealing } \\
\text { Tem. }{ }^{\circ} \mathrm{C}\end{array}$} & \multicolumn{2}{|c|}{$\begin{array}{c}\text { Amplified } \\
\text { Product size }\end{array}$} & \multirow{2}{*}{$\begin{array}{c}\text { Agarose } \\
\text { gel \% }\end{array}$} \\
\hline & & & & + & - & \\
\hline $\mathrm{ACE}$ & $17 \mathrm{q} 23$ & $\begin{array}{l}\text { F-5'-CTGGAGACCACTCCCATCCTTTCT-3' } \\
\text { R-5'-GATGTGGCCATCACATTCGTCAGAT-3-' }\end{array}$ & 58 & $490 \mathrm{bp}$ & $190 \mathrm{bp}$ & 2 \\
\hline
\end{tabular}

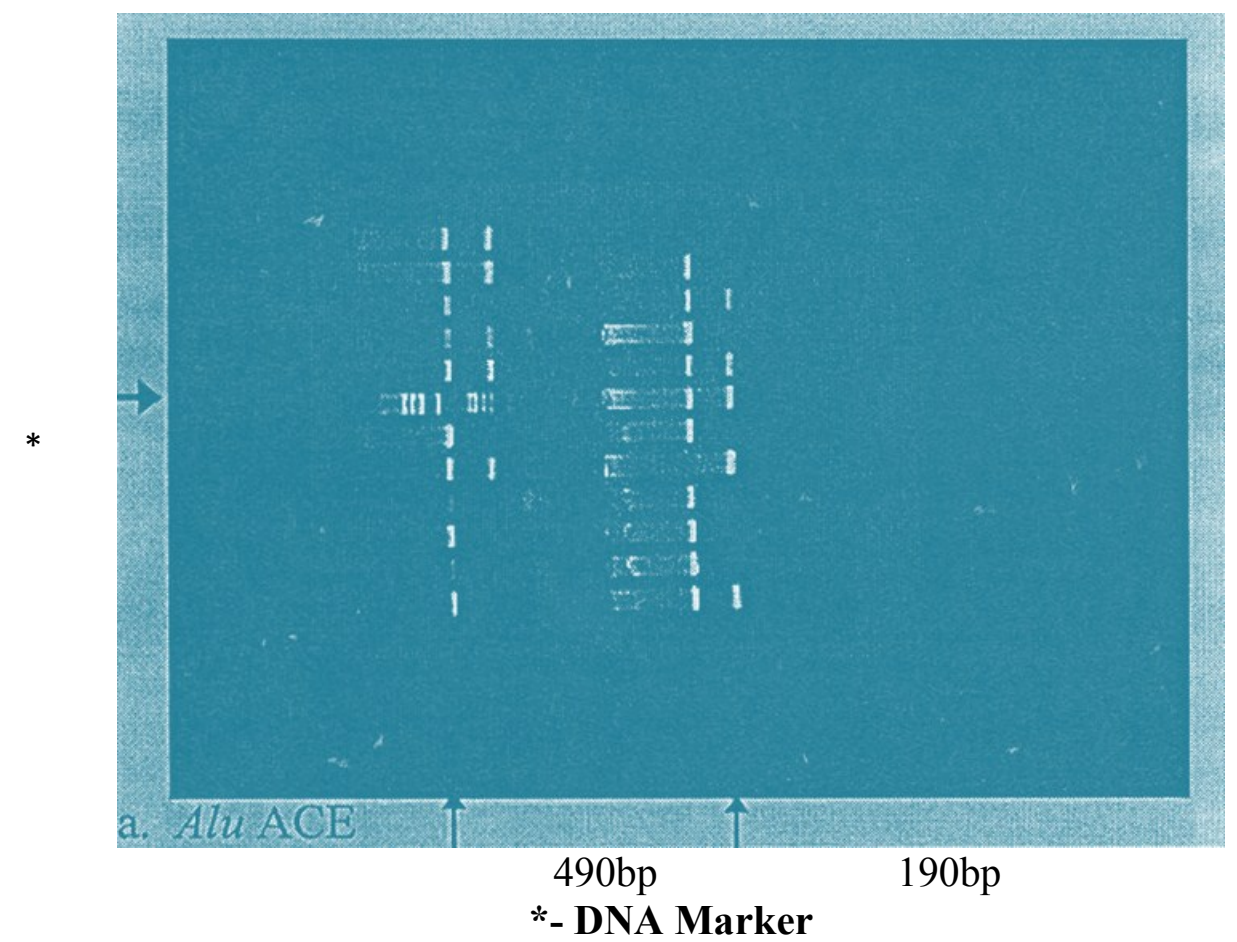

Fig. 1: Gel Patterns of Alu ACE Indels 


\section{Statistical analysis:}

The software package SPSS 16.0 was used for the analysis of odds ratio (OR), involving both the genotype and allele frequencies. The analyses of allelic associations using the $\chi^{2}$ test with $\mathrm{P}$ values $<0.05$ as significant, were performed using the population genetics package, POPGENE [39]

\section{Results:}

Table 2: Distribution of allele frequencies in Cases and Controls stratified according to gender.

\begin{tabular}{|c|c|c|c|c|c|c|c|c|c|c|}
\hline SNP & Gender & $\begin{array}{l}\text { Minor } \\
\text { allele }\end{array}$ & $\begin{array}{l}\text { Freq. } \\
\text { allele } \\
\text { case }\end{array}$ & $\begin{array}{l}\text { Freq. } \\
\text { allele } \\
\text { control }\end{array}$ & $\begin{array}{l}\text { Case } \\
(n=33)\end{array}$ & $\begin{array}{l}\text { Control } \\
(n=37)\end{array}$ & $\chi^{2}$ & $\overline{\text { OR }}$ & $95 \%$ CI & P-value \\
\hline \multirow{3}{*}{$\begin{array}{l}\mathrm{ACE} \\
\mathrm{I} / \mathrm{D}\end{array}$} & All & \multirow[t]{3}{*}{ I } & 0.29 & 0.64 & 33 & 37 & 13.39 & 1.0 & $0.616-1.602$ & 0.0135 \\
\hline & Female & & 0.38 & 0.68 & 20 & 20 & 10.03 & 0.65 & $0.323-1.307$ & 1.484 \\
\hline & Male & & 0.23 & 0.61 & 13 & 17 & 5.16 & 1.715 & $0.616-2.25$ & 0.108 \\
\hline
\end{tabular}

$\chi^{2}$ : Chi-square with 1 degree of freedom; OR: odds ratio

Table 3: Distribution of genotype frequencies of polymorphisms in Patients and Controls.

\begin{tabular}{|l|l|l|l|l|l|l|l|}
\hline SNP & Gender & Genotype & $\begin{array}{l}\text { Case\% } \\
(\mathbf{n = 3 3 )}\end{array}$ & $\begin{array}{l}\text { Control\% } \\
(\mathbf{n = 3 7 )}\end{array}$ & OR & $\mathbf{9 5 \%}$ CI & P-value \\
\hline ACE I/D & \multirow{2}{*}{ All } & II & $21.2(7)$ & $59.5(22)$ & \multicolumn{2}{|l|}{ Ref } \\
\cline { 3 - 8 } & & ID & $15.15(5)$ & $8.1(3)$ & 0.666 & 0.4143 .989 & 0.2 \\
\cline { 3 - 8 } & \multirow{2}{*}{ Female } & II & $63.6(21)$ & $32.4(12)$ & 1.0 & 0.4492 .225 & $0.0417^{*}$ \\
\cline { 3 - 8 } & & ID & $15(3)$ & $65(13)$ & \multicolumn{4}{|c|}{ Ref } \\
\hline
\end{tabular}

* Statistically significant. n: Sample size; OR: Odds ratio; CI: Confidence Interval; Ref: References.

Table 4: Distribution of ACE I/D polymorphisms (dominant and recessive model) in Patients and Controls.

\begin{tabular}{|l|l|l|l|l|l|l|l|l|}
\hline SNP & Gender & Model & TEST & $\begin{array}{l}\text { Case } \\
(\mathbf{n = 3 3 )}\end{array}$ & $\begin{array}{l}\text { Control } \\
\mathbf{( n = 3 7 )}\end{array}$ & OR & $\mathbf{9 5 \%}$ CI & P-value \\
\hline \multirow{3}{*}{$\begin{array}{l}\text { ACE } \\
\text { I/D }\end{array}$} & All & II+ID Vs DD & DOM & $12 / 21$ & $25 / 12$ & 0.84 & 0.4701 .5 & 0.1957 \\
\cline { 3 - 9 } & & II Vs ID +DD & REC & $7 / 25$ & $22 / 15$ & 1.136 & 0.6412 .015 & 0.085 \\
\cline { 3 - 9 } & Female & II+ID Vs DD & DOM & $9 / 11$ & $14 / 6$ & 1.5 & 0.5344 .214 & 0.267 \\
\cline { 3 - 9 } & II Vs ID +DD & REC & $6 / 14$ & $13 / 7$ & 0.785 & 0.3651 .73 & $0.00^{*}$ \\
\cline { 2 - 9 } & \multirow{2}{*}{ Male } & II+ID Vs DD & DOM & $4 / 9$ & $9 / 6$ & 1.0 & 0.3992 .51 & 0.06 \\
\cline { 3 - 9 } & & II Vs ID +DD & REC & $2 / 11$ & $9 / 8$ & 1.222 & 0.5071 .95 & $0.05^{*}$ \\
\hline
\end{tabular}

DOM:Dominant model: REC: Recessive model; n: sample size; OR: Odds ratio; CI: Confidence Interval: DOM model: Only when DD is present, the diseases would be caused, REC model: when $\mathrm{D}$ is in homozygous or heterozygous it will cause diseases.

* Statistically significant. 
Association studies between genetic polymorphisms and diseases are the hallmarks for unravelling the genetic pattern of complex diseases. Studying the relationship between allelic and genotype frequencies of candidate genes among both affected and healthy subjects, to understand the genetic etiology of complex human traits, is an efficient method to elucidate their disease pathogenesis .

Henceforth, we tried to elucidate the possible association of the ACE I/D polymorphisms with Hypertension among the tribal communities of South India. The D allele was observed to be more prevalent among cases than controls, as shown in Table 2 and 3. Genotype distributions, allelic frequencies and the corresponding odds ratios (OR) were calculated for each variants as shown in Table: 4.

No significant association was observed in the ungrouped data. However, when segregated the subjects into male and female, we found that the DD homozygous genotype has a significant prevalence upon females than in males. An increase in the frequency of DD (63.6\%) homozygous genotype was observed among the patients than controls (32.4\%) (Table:3). As shown in Table: 4, the distribution of the DD genotype is more dominant, when compared to the ID and II genotypes.

\section{Discussion:}

The gene encoding angiotensin converting enzyme (ACE) of RAS is polymorphic and frequently reported to be associated with Hypertension[40]. Epidemiological studies show that various genetic and environmental factors are involved in the pathogenesis of Hypertension. ACE is the key enzyme in the Renin-Angiotensin system, which can catalyze the conversion of Angiotensin-I to Angiotensin-II [22,24,41].The ACE gene is located in chromosome 17q23 and contains 26 exons and 25 introns with a total length of $21 \mathrm{~kb}$. The Insertion/Deletion (I/D) polymorphisms are defined according to presence or absence of the $287 \mathrm{bp}$ fragment in intron 16 .

Alu elements are mobile gentic elements [42]. deriving their name from the Alu I restriction sites they comprise [43]. ACE gene is one of the insertional polymorphisms of Alu elements [4445]. Many reports studied the Alu polymorphisms in the context of human genetics and evolution [46-53] .

Recently, various studies reported the relationship between ACE gene polymorphism and Type 2 Diabetes. For example, the recently published meta-analysis [51], comprising a total of 41 studies with 4708 cases and 5368 controls, analyzed the association between ACE I/D polymorphisms and Type 2-Diabetes in Chinese population. Another report on Egyptian populations suggests that the DD genotype and the D allele are associated with hypertension and Type 2 Diabetes[55]. The exact role of ACE gene in the onset of hypertension remains controversial. Woo et al, [56] reported that the ACE gene is not associated with hypertension. However, in other population-based studies, the D allele was found to be associated [56-58].

The present study revealed the association of ACE genotypes with hypertension among the tribal population $(n=70)$ of the Southern region of India. In contrast to the urban populations, these tribal populations represent a genetically homogenous primitive population subgroups, where the former is highly heterogenous in nature. Hence, studies with these demographically isolated communities could yield valuable results in the field of medical genetics and history and anthropology. In this study, we utilized the common Case-control design to analyze these associations. The DD homozygous genotype is found to be associated with hypertension. The same ACE DD genotype is also reported to be associated with diabetic nephropathy in north indian populations [59].

Since, the genetic matrix is a non-modifiable factor in the causation of diseases, greater attention should be given to modify the environmental factors. The clinicians could identify groups of patients, with the susceptible ACE genotypes that need intensive monitoring and correct the risk factors such as smoking, alcohol consumption and high BMI for an effective prevention of both onset and the development of hypertension . 


\section{Conclusion}

In conclusion, a significant association of the DD genotype with hypertensive patients, especially, with females of the tribal populations was observed. With the observed association of II/DD genotype with hypertension, this study anticipates more studies with larger cohorts to extend and elucidate these associations.

\section{Aknowledgement}

Authors also acknowledge the UGC, New Delhi for finanacial support.

\section{References}

[1]. Xing J, Wuren T, Simonson TS, Watkins WS, Witherspoon DJ, Wu W, Qin G, Huff CD, Jorde LB , Ge R . 2013. Genomic Analysis of Natural Selection and Phenotypic Variation in HighAltitude Mongolians. PLoS Genet. 9 (7) :1-13.

[2]. Pitchappan RM. 2002. Castes, Migration, Immunogenetics and infectious diseases in South India. Community Genetics. 5: 157-161.

[3]. Tamang R and Thangaraj K. 2012.Genomic view on the peopling of India. Investigative Genetics. $3: 20: 1-9$.

[4]. Sugunan AP, Ghosh AR, Subarna Roy, Gupte MD, and Sehgal SC. 2004. A cholera epidemic among the nicobarese tribe of nancowry, andaman, and nicobar, India. Am. J. Trop. Med. Hyg. 71(6). pp. 822-827.

[5]. Haimanti Bhattacharya, Debdutta Bhattacharya, Subarna Roy, and Sugunan AP. 2014. Occult hepatitis B infection among individuals belonging to the aboriginal Nicobarese tribe of IndiaJ Infect Dev Ctries. 8 (12) :1630-1635. doi:10.3855/jidc.4350.

[6]. Sharma PR, ain S, Bamezai R N K and Tiwari1 P K. 2010. Utility of serum ldh isoforms in the assessment ofmycobacterium tuberculosis induced pathology in tb patients ofsahariya tribe Indian Journal of Clinical Biochemistry. 25 (1) 57-63.

[7]. Balgir RS. 2010. Genetic diversity of hemoglobinopathies, G6PD deficiency, and ABO and Rhesus blood groups in two isolates of a primitive Kharia Tribe in Sundargarh District of Northwestern Orissa, India J Community Genet . 1:117-123. DOI 10.1007/s12687-010-0016-y

[8]. Deepak Bharti, Ashish Kumar, Ranjeet Singh Mahla, Sushil Kumar, Harshad Ingle, Tushar Yadav,Anamika Mishra, Ashwin Ashok Raut and Himanshu Kuma. 2015. Low prevalence of CCR5- 332 , CCR2-64I and SDF1-3'A alleles in the Baiga and Gond tribes of Central India . SpringerPlus. 4: 451 DOI 10. 1186/s40064-015- 1238-6.

[9]. Murhekar MV, Murhekar KM . Arankalle VA . and Sehgal. SC. 2002. Epidemiology of hepatitis B infection among the Nicobarese a mongoloid tribe of the Andaman and Nicobar Islands, India Epidemiol. Infect.128, 465 - 471. DOI:10.1017\} S095026880200691X

[10]. Ruchira Chaudhary and Gunjan Sharma. 2010 Genetic assessment of serological and biochemical markers in Bharia tribe of Chhindwara district of Madhya Pradesh. Indian Journal of Human Genetics . Vol.16 Iss. 3

[11]. Sharma G, Tamang R, Chaudhary R, Singh VK, Shah AM, Anugula S, Rani DS, Reddy AG, Eaaswarkhanth M, Chaubey G, Singh L and Thangaraj K. 2012. Genetic Affinities of the Central Indian Tribal Populations. PLoS ONE 7(2): e32546. doi:10.1371/journal.pone.0032546.

[12]. Bhuniya S, Maji D, Mandal D and Mondal N. 2013. Measles outbreak among the Dukpa tribe of Buxa hills in West Bengal, India: Epidemiology and vaccine effi cacy. Indian J Public Health . 57:272-5 
[13]. Ashok K. Kayal, Munindra Goswami, Marami Das, and Hussain Masaraf. 2011. A case of Spinocerebellar Ataxia from ethnic tribe of Assam. Ann Indian Acad Neuro.14: 122-3

[14]. Rao VG, Gopi PG, Bhat J, Selvakumar N, Yadav R, Tiwari B, Gadge V, Bhondeley MK, and Wares F. 2010. Pulmonary tuberculosis: a public health problem amongst the Saharia, a primitive tribe of Madhya Pradesh, Central India International Journal of Infectious Diseases. 14 e713-e716.

[15]. Krithika S, Maji S and Vasulu TS. 2008. A Microsatellite Guided Insight into the Genetic Status of Adi, an Isolated Hunting-Gathering Tribe of Northeast India. PLoS ONE . 3(7): e2549. doi: 10.1371 / journal.pone.0002549.

[16]. Rao VG, Gopi PG, Bhat J, Yadav R, Selvakumar N, and Wares DF. 2010. Selected risk factors associated with pulmonary tuberculosis among Saharia tribe of Madhya Pradesh, central India European Journal of Public Health. Vol. 22, No. 2, 273 - 278.

[17]. Thurston E and Rangachari K . Castes and Tribes of Southern India. 1909. I -V I I (A and Z), Madras: Government Press. Retrieved 2011.

[18]. Singh KS. The Scheduled Tribes . Anthropological Survey of India, 1992. (National Series Vol. III). Oxforod University Press. Retrieved 2010.

[19]. Vishwanathan H, Edwin D, Cordaux R, Stoneking M, Usha Rani MV. and Majumder PP. 2004. Genetic structure and affinitiesamong tribal populations of southern India: a study of 24 auto-somal DNA markers.Ann. Hum. Genet. 68, 128-138.

[20]. Kanthimathi A, Vijaya M, and Ramesh A. 2008. Genetic study of Dravidian caste of Tamil Nadu. J Genet. 87(2) : 175-179.

[21]. Deva A, Nandakumar R, Raghu P and Prabhakaran K. 2016. Autosomal DNA Polymorphisms of Four South India Tribal Populations. WSN (2016). 35.62-72.

[22]. Fei Zhou Y, Yan Y, Ping Hou X, Miao J, Zhang J, Xiang Yin Q, Jie L J, Xiao- Zhang Y,Yuan $\mathrm{Li}$ and Yand Lan Luo H. 2013. Association study of Angiotensin converting enzyme gene polymorphism with elderly diabetic hypertension and lipids levels. Lipids in Health and Disease 12:187.

[23]. Xia H, Sriramula S, Chhabra KH and Lazartigues E. 2013. Brain Angiotensin-converting enzyme type shedding contributes to the development of neurogenic hypertension. Circ Res 113(9):1087-96.

[24]. Chaoxin J, Daili S, Yanxin H, Ruwei G, Chenlong W and Yaobin T. 2013. The influence of angiotensin-converting enzyme 2 gene polymorphisms on type 2 diabetes mellitus and coronary heart disease. Eur Rev Med PharmacolSci. 17(19):2654-9.

[25]. Muñoz-Barrios S, Guzmán-Guzmán IP, Muñoz-Valle JF, Salgado-Bernabé AB, SalgadoGoytia L and Parra-Rojas I. 2012. Association of the HindIII and S447X polymorphisms in LPL gene with hypertension and type 2 diabetes in Mexican families. Dis Markers. 33 (6) : 313-20.

[26]. Zarouk WA, Hussein IR, Esmaeil NN, Raslan HM, Reheim HA, Moguib O, Emara NA, Aly AA, and Hamed M. 2012. Association of angiotensin converting enzyme gene (I/D) polymorphism with hypertension and type 2 diabetes. Bratisl Lek Listy . 113 (1):14-8.

[27]. Al-Rubeaan K, Siddiqui K, Saeb AT, Nazir N, Al-Naqeb D, Al-Qasim S. 2013. ACE I/D and MTHFR C677T polymorphisms are significantly associated with type 2 diabetes in Arab ethnicity: a meta-analysis. Gene. 520 (2) : $166-77$.

[28]. Al-Harbi EM, Farid EM, Gumaa KA, Darwish AH, Alenizi M and Singh J. 2013. Genetic combination of angiotensin-converting enzyme with methylene tetrahydrofolate reductase polymorphisms and the risk of type 2 diabetes mellitus in Bahrain. J Renin Angiotensin Aldosterone Syst doi: 10.1177/1470320313478286 
[29]. Purnamasari D, Widjojo BD, Antono D, and Syampurnawati M. 2012. ACE gene polymorphism and atherosclerotic lesion of carotid artery among off springs of type 2 diabetes mellitus. Acta Med Indones . 44 (2) : 128-34.

[30]. Narne P, Ponnaluri KC, Singh S, Siraj M, and Ishaq M. 2012. Relationship between angiotensin-converting enzyme gene insertion/deletion polymorphism, angiographically defined coronary artery disease and myocardial infarction in patients with type 2 diabetes mellitus. J Renin Angiotensin Aldosterone Syst. 13 (4) : 478-86.

[31]. Sinorita H, Madiyan M, Pramono RB, Purnama LB, Ikhsan MR and Asdie AH. 2010. ACE gene insertion/deletion polymorphism among patients with type 2 diabetes, and its relationship with metabolic syndrome at Sardjito Hospital Yogyakarta, Indonesia. Acta Med Indones . 42(1):12-6.

[32]. Niu W, Qi Y, Gao P, and Zhu D. 2010. Angiotensin converting enzyme D allele is associated with an increased risk of type 2 diabetes: evidence from a meta-analysis. Endocr J . 57 (5) : 431-8.

[33]. Chmaisse HN, Jammal M, Fakhoury H, and Fakhoury R. 2009. A study on the association between angiotensin-I converting enzyme I/D dimorphism and type-2 diabetes mellitus. Saudi J Kidney Dis Transpl. 20 (6) : 1038 - 46.

[34]. Rasyid H, Bakri S, and Yusuf I. 2012. Angiotensin-converting enzyme gene polymorphisms, blood pressure and pulse pressure in subjects with essential hypertension in a South Sulawesi Indonesian population. Acta Med Indones . 44 (4) : $280-3$.

[35]. Zhu M, Zhang J, Nie S and Yan W. 2012 Associations of ACE I/D, AGT M235T gene polymorphisms with pregnancy induced hypertension in Chinese population: a meta-analysis. $\mathrm{J}$ Assist Reprod Genet . 29 (9) : 921-32.

[36]. Miller SA, Dykes DD and Poesky HF 1988. A Simple Salting Out Procedure Form Extracting DNA From Human Nucleated Cells. Nucleic Acids Res.70: 3321- 3323.

[37]. Stoneking M, Fontius JJ, Clifford SL, Soodyall H, Arcot S et al.1997. Alu insertion/ deletion polymorphism and human evolution: Evidence for a larger population size in Africa. Genome Res. 7: $1061-1071$.

[38]. Majumder PP, Roy B, Banerjee S, Chakraborty M, Dey B et al.1997. Human - specific insertion/deletion polymorphisms in Indian populations and their possible evolutionary implications. Eur J Hum Genet. 7: 435-446

[39]. Yeh FC, and Yang RC. A Joint Project Development: POPGENE 1.32. Centre for International Forestry Research. Canada: University of Alberta and TimBoyle. 1999.

[40]. Cowie CC, Port FK, Wolfe RA, Savage PJ, Moll PP and Hawthorne VM. 1989. Disparities in incidence of diabetic end-stage renal disease according to race and type of diabetes. $\mathrm{N}$ Engl $\mathrm{J}$ Med. 321: 1074-9.

[41]. Zhu M, Zhang J, Nie S and Yan W. 2012. Associations of ACE I/D, AGT M235T gene polymorphisms with pregnancy induced hypertension in Chinese population: a meta-analysis. J Assist Reprod Genet . 29 (9) : 921-32.

[42]. Haynes SR, Toomey TP, Leinwand L, and Jelinek WR. 1981. The Chinese Hamster AluEquivalent Sequence: a Conserved, Highly Repetitious, Interspersed Deoxyribonucleic Acid Sequence in Mammals Has a Structure Suggestive of a Transposable Element. Moleu. and cellu. Bio. 1(7) p. 573-583

[43]. Houck CM, Rinehart FP and Schmid CW. 1979. A ubiquitous family of repeated DNA sequences in the human genome. J Mol Biol .132: 289-306. 
[44]. Comas D, Calafell F, Benchemsi N, Helal A, Lefranc G, Stoneking M, Batzer MA, Bertranpetit $J$ and Sajantila A. 2000. Alu insertion polymorphisms in NW Africa and the Iberian Peninsula:evidence for a strong genetic boundary through the Gibraltar Straits. Hum Genet.107: 312-319.

[45]. Nasidze I, Risch GM, Robichaux M, Sherry ST, Batzer MA and Stoneking M. 2001. Alu insertion polymorphisms and the genetic structure of human populations from theCaucasus. Eur $\mathrm{J}$ Hum Genet. 9: 267-272.

[46]. Harun Mustafa, Matei David and Michael Brudno. 2014. Assembly and characterization of novel Alu inserts detected from next-generation sequencing data. Mobile Genetic Elements 4:5. 17.

[47]. Schilter KF, Reis LM, Sorokina EA and Semina EV. 2015. Identification of an Alu-repeatmediated deletion of OPTN upstream region in a patient with a complex ocularphenotype. Molecular Genetics \& Genomic Medicine. 3(6): 490 - 499.doi: 10.1002/mgg3.159.

[48]. Wildschutte JH, Baron A, Diroff NM, Kidd JM. 2015. Discovery and characterization of Alu repeat sequences via precise local read assembly. Nucleic Acids Research.43.(21).doi: 10.1093/nar/gkv1089.

[49]. Rishishwar L, Tellez Villa CL and King Jordan I. 2015. Transposable element polymorphisms recapitulate human evolution. Mobile DNA . 6:21 DOI 10.1186/s13100-015-0052-6.

[50]. Siu-Kin Ng, Taobo Hu, Xi Long, Cheuk-Hin Chan, Shui-Ying Tsang and Hong Xue. 2016. Feature co-localization landscape of the human genome. Scientific Reports. 6:20650 DOI: 10.1038/srep20650.

[51]. Qian Y, Kehr B and Halld Orsson BV.2015 .PopAlu: population-scale detection of Alu polymorphisms. Peer J .3:e1269. DOI 10.7717/peerj.1269.

[52]. Sang-Je Park, Young-Hyun Kim, Sang-Rae Lee, Se-Hee Choe, Myung-Jin Kim, Sun-Uk Kim,Ji-Su Kim, Bo-Woong Sim, Bong-Seok Song, Kang-Jin Jeong, Yeung-Bae Jin, Youngjeon Lee1 Young-Ho Park, Young Il Park, Jae-Won Huh and Kyu-Tae Chang. 2015. Gain of a New Exon by a Lineage-Specific Alu Element-Integration Event in the BCS1L Gene during Primate Evolution. Mol. Cells . 38(11): 950958m http://dx.doi.org/10.14348/molcells.2015.0121.

[53]. Kaur S and Pociot F. 2015. Alu Elements as Novel Regulators of Gene Expression in Type I Diabetes Susceptibility Genes?.Genes 2015. 6. 577-591; doi:10.3390/genes6030577.

[54]. Zhou D, Ruiter R, Zhang J, Zhou M, Liu H, Liu W and Wang S 2012. Angiotensin converting enzyme I/D polymorphism is not associated with type 2 diabetes in a Chinese population. J Renin Angiotensin Aldosterone Syst. $13: 372-8$.

[55]. Bhaskar LV, Mahin S and Ginila RT, Soundararajan P. 2013. Role of the ACE ID and PPARG P12A Polymorphisms in Genetic Susceptibility of Diabetic Nephropathy in a South Indian Population. Nephrourol Mon. 5 (3) : 813-817.

[56]. Woo SW, Bang S, Chung MW, Jin SK, Kim YS and Lee SH. 2009. Lack of association between ACE and bradykinin B2 receptor gene polymorphisms and ACE inhibitor-induced coughing in hypertensive Koreans. J Clin Pharm Ther . 34 (5) :561-7.

[57]. He Q, Fan C, Yu M, Wallar G, Zhang ZF, Wang L, Zhang X and Hu R 2013. Associations of ACE Gene Insertion/Deletion Polymorphism, ACE Activity, and ACE mRNA Expression with Hypertension in a Chinese Population. PLoS One . 8(10):e75870.

[58]. Zivko M, Kusec R and Galesić K. 2013. Impact of angiotensin-converting enzyme gene polymorphism on proteinuria and arterial hypertension. Coll Antropol. 37:765-770.

[59]. Haque SF, Ahmad M, Khan AU, Gupta V and Khan AS. 2010. ACE Insertion / Detetion gene polymorphism and sequence in Diabetic nephropathy. Int J Diabetes \& Matab . 18:14-118. 